\title{
NOTES ON THE GEOLOGY OF THE LANGDON HILLS, ESSEX.
}

With Report of Excursion, May 6TH, ig22.

By S. W. Wooldridge, B.Sc., F.G.S., aNd Herbert C. Berdinnter, Directors of the Excursion.

THE party proceeded southward from Laindon Station over the flank of the Langdon Hills to West Lee Hall, where a pit in the Lower Bagshot Sands was inspected and a brief discussion took place on the relation of the Bagshot Pebble Bed to the Pebble Gravel. On the way eastward to Vange, magnificent views across the Thames estuary to Sheppey and the North Downs were enjoyed. On arrival at Vange Hall the party examined a good section in beds of Claygate facies resting on London Clay with fossiliferous septaria. There were indications of shallow Roman excavations at the top of the pit. The return was made from Pitsea station.

It has been apparent for some time that the outliers of Bagshot Sand scattered over the London Clay tract in Essex need re-examination. No systematic work has been done on these beds since they were mapped and briefly described by the Geological Survey.* They present, however, many points of interest bearing on Eocene stratigraphy, and we shall here attempt to indicate the conclusions to which we have been led by an examination of some of the outliers.

The Langdon Hills and their neighbourhood provide material for the discussion of many of the points we wish to emphasize. Rising to a height of 385 feet O.D. from a low-lying London Clay area, the main hill consists of an outlier of some $70 \mathrm{ft}$. of sandy beds resting on London Clay. The lower part of this sandy series should doubtless be classed with the London Clay, representing passage beds such as have been called the Claygate Beds farther west. It is difficult, if not impossible, to map these passage beds : the line indicated by springs and by features corresponds with the junction of a generally sandy series above with the great mass of clay below. A thin capping of pebbles exists on top of the outlier.

Between the main outlier and Vange are a number of small sand patches, each capping a hill. Five such patches can be distinguished, one at One Tree Hill, two near Hawkesbury Bush, and two at Vange Hall.

The Lower Bagshot Sands as seen at West Lee Hall and elsewhere on the main outlier, as well as at One Tree Hill, roo yards west of the road, comprise exceedingly fine-grained sands, grey or brown in colour, associated in places with a little brown

* Mem. Geol. Surv., vol. iv., 1872, pp. 320 et seq. The descriptions are repeated in the later edition of 1889 . 
loam. They show no current-bedding, indeed they are practically unbedded as seen in small sections, and pipe-clay bands are absent. Ferruginous casts of lamellibranchs resembling Pectunculus and Cyprina have been found in certain layers, and even where these are absent the beds locally have the appearance of a decalcified shelly sand, the shapes of the shells being preserved as casts in a scarcely compacted sandy clay.

Doubt has been expressed in the past as to whether the Bagshot Sands of Essex are true Lower Bagshots. Monckton,* referring to Prestwich's $\dagger$ description of green beds in the Bagshot Sands of Brentwood, suggested that Bracklesham Beds were there represented. If this were so it would follow that the Bagshot Pebble Bed of Essex is equivalent to the pebble bed at the base of the Upper Bagshot Sands in Surrey and Hampshire. Whitaker + and $\mathrm{H}$. B. Woodward $\S$ have conclusively answered these doubts, emphasizing among other things the existence of the passage beds mentioned above, which clearly indicate the Lower Bagshot age of the overlying sands.

Although, however, the Lower Bagshot age of these sands has been fairly conclusively proved, it is not generally realized that there was a definite reason for the doubts formerly expressed, suggesting affinity with the Bracklesham Beds. That reason may be briefly stated thus-that the Lower Bagshot Sands, white fluviatile or possibly estuarine in the west, show evidence of marine conditions as they are traced east into Essex. Opinion has varied as to the conditions under which the beds were deposited. Prestwich\| considered them marine, but Irving supported a fluviatile or estuarine origin on grounds which must be considered adequate. The latter author referred to the beds in the main Bagshot tract where the sands are coarse and currentbedded, and contain layers of pipe-clay. Stamp** recently accepted Irving's conclusion in regarding the Lower Bagshot Beds as the "continental" phase of the Ypresian cycle.

The range of the Lower Bagshot Beds from east to west in the London basin (from near Hungerford to the Isle of Sheppey) is about roo miles, and if we adopt Stamp's view that the bulk of the beds are fluviatile and estuarine we may still hope to find signs of the incoming of marine conditions in the more easterly outliers. It is, therefore, significant that the criteria relied on to. prove fluviatile origin in the west fail in mid-Essex. West of a line running N.S. through Brentwood, we have current-bedded unfossiliferous sands. At Brentwood we encounter in its most typical development the Bagshot Pebble Bed, while to the

* Nature, vol. xlii., I890, p. 198. See also Irving, ibid., p. 222.

$\dagger$ Quart. Jourm. Geol. Sot., vol, xlvi., i 890 , p. I52.

† "Geology of London," vol. i., Mem. Geol. Surv., I 889 , p. 267.

" The Geology of the London District," $M \mathrm{em}$. Geol. Surv., I909, pp. 38-30.

Quart. Journ. Geol. Soc., vol. xlii., 1886, p. I7 I.

Geol. Mag., i 89 r, p. 357 .

* Geol. Mag., vol. lviii., 192 I, p. Igf. 
east of the line the beds are of the type described at Laindon. It is also significant that at two places east of Brentwood, marine fossils have been found, at Mill Green by Monckton and Herries* and at Iaindon. $\uparrow$ The lithology of the beds as described above is further suggestive of marine origin. The thick-bedded character of the sands and the absence of clay lamina indicate that sand and clay were precipitated together, which, since clay substance is largely colloidal, can only occur in the presence of an electrolyte which flocculates the clay. In fresh water the clay grade (of which the sand in question contains a considerable proportion) remains suspended at first, and settles down much more slowly than the sand, thus producing a lamination.+

We would, therefore, suggest that the Bagshot Pebble Bed is in the nature of a shingle-bank separating a fluvio-estuarine from a marine facies. It seems to occupy a N.S. band running through Essex; it does not occur at High Beech on the West or at Rayleigh on the East. We have found no sign of it at Laindon, but Mr. A. Wrigley informs us that he saw a few thin patches of a flint gravel underlying the drift cap in a section which has since disappeared.

It is noteworthy that the Pebble Bed contains some very large flint pebbles-up to six inches in greatest diameter, and that all the pebbles show the arcuate surface-cracking which has been called " beach-noding " and considered as indicative of marine origin. The pebbles too have a peculiar shape when compared with those from other Tertiary pebble beds, being commonly cylindrical rather than ovoid. This seems to imply a predominance of a rolling over a sliding motion, but we hesitate to draw any conclusions at present as to the value of this feature as a criterion of origin. Further evidence on the point is being sought.

Turning to the beds of Claygate facies inspected by the Association, 300 yards S.E. of Vange Hall, one point of interest may be noted. The beds reproduce in detail the characters of the Claygate Beds of Surrey. Resting on London Clay, which yields a few fossils including Rostcllaria lucida, Astarte sp. and Vatica sp., are bands of fairly coarse current-bedded sand alternating with bands of clay, identical in character with London Clay. The clay bands become less prominent upwards and finally die out altogether. There is also a striking similarity between these beds and the Oldhaven Beds seen in recent sections at Boughton-under-Blean in the Faversham district. Thus the Ypresian Beds provide a singularly complete and convincing example of a cycle of sedimentation comprising a thick mass of clay passing both upwards and downwards into essentially similar sandy beds.

* "Geology of London," vol. i., pp. $266,276$.

$\dagger$ Dr. A. E. Salter, notes the presence of fossils at Laindon, but does not mention their nature, Pror. Gcol. Assoc., vol. xx., 1907, p. $18 \mathrm{I}$.

\pm cf. W. A. Johnston, Journ. of Gcol., vol. xxx., 1 1,22, pp. 124, $128-9$. 


\section{THE GRAVELS.}

Thin gravel patches cap the Bagshot Sands of the Langdon Hills and are exposed in lower situations as hill-wash. Composed chiefly of Tertiary flint pebbles from $I$ to 3 inches in diameter, the gravel also contains Lower Greensand Chert and a few small quartz pebbles. The thickness of the deposit appears to be from 3 to 5 feet.

These gravels have been variously classed. They were originally mapped as Bagshot Pebble Bed. In a subsequent drift edition of the map they were transferred to the category of " plateau gravels." In I888 Mr. Whitaker* expressed an opinion that both Bagshot Pebble Bed and Drift were present, the former predominating. Later Dr. Salterf appears to have regarded the whole accumulation as drift gravel and he pointed out that it must have been derived from the Wealden area before the development of the Lower Thames Valley.

Our view is that the gravels were carried down the northern flank of the Weald through the notch which has since been widened into the Medway Gap. The relation to this gap is very strongly suggested by a study of the map. As tending to confirm the idea we may note that the gravel resting on London Clay near Boughton-under-Blean (Kent) is similarly situated with regard to the Stour Gap. Here, however, Lower Greensand Chert is missing, the gravel being composed almost wholly of flint. This may be ascribed to the fact that the cherty facies of the Hythe Beds is developed round the Medway Gap, but not round the Stour Gap.

As regards age we consider it most in accord with facts to refer this gravel to the Middle or Upper Pliocene. A Lower Pliocene age seems inadmissible, since deposits of that age should show a northerly tilt due to the subsequent uplift along the Wealden axis - a tilt which is clearly shown by the French and Belgian Diestian beds. Taking the gravel at Laindon together with others of similar nature such as those at Rayleigh, Billericay, etc., no such tilt is discernible.

On the other hand the gravels are clearly Pre-Glacial. Denudation had removed some 200 feet of London Clay from parts of the district before the advance of the Chalky Boulder Clay icesheet.

Hence we fe: 1 justified in assigning the beds to the latter part of Pliocene times.

* Proc. Grol. Assoc, vol. x., 1888, p. 4 so.

† Proc. Guol. issoi., vol. xx., rori, p. 182. 